\title{
Does Islamic Banking Augment Financial Inclusion in Pakistan? A Reinforcement Analysis
}

\author{
Muhammad Hanif Akhtar ${ }^{a}$, Imran Sharif Chaudhry ${ }^{b}$, Muhammad Ramzan Sheikh ${ }^{c}$ \\ ${ }^{a}$ Professor, Department of Commerce, Bahauddin Zakariya University Multan, Pakistan \\ Email: haneefakhtar@gmail.com \\ ${ }^{\mathrm{b}}$ Professor, School of Economics, Bahauddin Zakariya University, Multan Pakistan. \\ Email: imran@bzu.edu.pk \\ ${ }^{c}$ Associate Professor, School of Economics, Bahauddin Zakariya University, Multan Pakistan \\ Email: ramzansheikh@bzu.edu.pk
}

\begin{tabular}{ll}
\hline ARTICLE DETAILS & ABSTRACT \\
\hline History: & This study spells out the role of financial inclusion (FI) to accelerate the \\
Accepted 18 Nov 2020 & efficiency of Islamic banks in Pakistan for the period of 2007 to 2016. It \\
Available Online 31 Dec 2020 & examines the effect of a specially developed broad-based FI index on \\
& technical efficiency of Islamic banks through panel ARDL approach along \\
Keywords: & with to explore the macroeconomic as well as bank-specific factors of \\
Financial Inclusion, Efficiency, & efficiency. The findings exhibit the possible connection between Islamic \\
Islamic Banking & banking and financial inclusion in Pakistan. The study offers a variety of \\
& useful policy implications for public policy towards effective progress on \\
& the National Financial Inclusion Strategy in the country.
\end{tabular}

JEL Classification:

G17, G21

DOI: $10.47067 /$ reads.v6i4.275

(C) 2020 The authors. Published by SPCRD Global Publishing. This is an open access article under the Creative Commons Attribution-

NonCommercial 4.0

Corresponding author's email address: imran@bzu.edu.pk

\section{Introduction}

The axiom of financial inclusion (FI) has attracted the attention of research scholars, policy makers and economists across the globe. An augmentation in financial inclusion is expected to ensure fuller participation by economically vulnerable and weaker segments and low-income groups in the economy. FI is defined as a process that ensures the ease of access, availability and usage of the formal financial system for all members of an economy (Sarma and Pais, 2011). The financial inclusion process is carried out through the formal as well as informal sources of finance; Commercial banks in general and Islamic banks in particular are equally important in this drive both being contributory as well as beneficiary. There stands an immense contribution by the banks towards development of financial inclusion activity. Financial markets have gone through significant changes largely due to positive developments in technological and innovative products. These factors have contributed towards financial inclusion development vis-à-vis improvement in efficiency of banks. Given the dearth of literature on the role of Islamic banks towards financial inclusion, empirical research on the role of Islamic banks and their contribution towards financial inclusion becomes inexorable. 


\section{Review of Economics and Development Studies, Vol. 6 (4) 2020, 739-758}

The present study intends to investigate the role of Islamic banks towards financial inclusion as well as the contribution of latter towards performance of Islamic banks in Pakistan. The relationship is an important issue to be explored since Islamic banks generate deposits and then turn these into advances taking the form of Murabaha, Ijarah, Istisna'a and Salam etc. overtime. To what extent these products have been useful in augmenting financial inclusion in the country and what has been the effect of FI towards improvement in performance of these banks. The study intends to explore this issue at three stages where the financial inclusion index (FII) is developed at first stage. The bank performance is estimated through the lens of technical efficiency (TE) by using the data envelopment analysis (DEA) at the second stage while the contribution of Islamic banking towards promotion of financial inclusion along with the effect of financial inclusion across bank efficiency is evaluated at the third stage. The third stage analysis is conducted through the use of autoregressive distributed lag (ARDL) model. Since the number of Islamic banks is too small in Pakistan, the study adopts a panel data approach for estimation. Hence, the present research, being the first of its type on development of financial index in Pakistan, is an attempt to fill the gap and make a valuable contribution both for policy makers and bank executives in the country. This is also anticipated in expanding the role of Islamic banks towards FI in line with the recent National Financial Inclusion Strategy (NFIS) launched by the government of Pakistan vis-à-vis role of the latter towards improving performance of the formers.

Rest of the paper is organized as under. The next section reviews the literature on financial inclusion and bank efficiency around the globe. Section 3 takes care of the developing the index of financial inclusion. Section 4 draws upon the research methodology adopted towards reaching the ultimate goal of testing the contribution of Islamic banks towards financial inclusion. Section 5 presents major findings through the lens of technical efficiency of banks as well as the role of Islamic banks towards augmenting financial inclusion in Pakistan. The final part concludes with policy implications.

\section{Review of Assorted Literature}

The measurement of financial institutions' efficiency using non-parametric frontier models has received considerable attention over the past two decades. There exists a great amount of literature on bank efficiency across the globe. Among the various approaches used, the use of Data Envelopment Analysis (DEA) approach has been frequent. However, there exists a difference of choice among various studies across variables being used as inputs or outputs. The following discussion refers to some of the studies that have been conducted in context of the issue under consideration.

There exist only a few studies on the determinants of financial inclusion as well as on the development of financial inclusion index worldwide. This is not the case for efficiency analysis of banks where plenty of literature is visible in an immense volume across the world. However, it is difficult to trace a significant amount of literature on the role of Islamic banks towards financial inclusion. Thus, a brief review of literature in these perspectives is presented in Table 1.

It can be observed that the literature on financial inclusion is limited but growing overtime. One can hardly find a study on the role of Islamic banks towards financial inclusion except for the one by Naceur et. al (2015). Hence, the present study is an attempt to extend the literature in various dimensions that have not been addressed by the extant studies. In terms of financial inclusion index, the study has extended the inclusion of more dimensions that have not been considered before in construction of the index. The FII is expected to be useful measure of financial inclusion for understanding the changes at a given time vis-à-vis over a period of time. Having developed the index, the study attempts to determine the influence of Islamic banks on financial inclusion and subsequently the effect of financial inclusion towards efficiency of banks through the use of ARDL approach. 
Table 1: Assorted Studies on Bank Efficiency, FII and Determinants of Financial Inclusion

\begin{tabular}{|c|c|c|c|c|}
\hline Reference (s) & $\begin{array}{l}\text { Time Period } \\
\text { Covered }\end{array}$ & Country & Methodology & Main Results \\
\hline \multicolumn{5}{|c|}{ A) Studies on Technical Efficiency Analysis } \\
\hline $\begin{array}{l}\text { Jackson and Fethi } \\
(2000)\end{array}$ & 1998 & Turkey & $\begin{array}{l}\text { DEA and Tobit } \\
\text { analysis }\end{array}$ & $\begin{array}{l}\text { They discovered the larger and profitable banks were to } \\
\text { perform at higher levels of technical efficiency while the } \\
\text { capital adequacy ratio had a statistically significant negative } \\
\text { effect on performance of Turkish banks. }\end{array}$ \\
\hline $\begin{array}{l}\text { Al-Muharrami } \\
(2008)\end{array}$ & $1993-2002$ & DEA & GCC & $\begin{array}{l}\text { Smaller banks exhibited a better performance in terms of } \\
\text { overall TE than did their large counterparts. The study found } \\
\text { the big banks were more successful in adopting the best } \\
\text { available technology, while medium banks proved good for } \\
\text { optimal levels of output. Islamic banks in the GCC area were } \\
\text { seen as more successful in both adoption of best available } \\
\text { technology and choosing optimal output levels. Finally, in } \\
\text { terms of TE, the banks from Bahrain emerged as the top } \\
\text { performers in the region followed by peers from Qatar. }\end{array}$ \\
\hline $\begin{array}{l}\text { Sufian and Noor } \\
(2009)\end{array}$ & 2001-2006 & MENA & DEA & $\begin{array}{l}\text { The technical inefficiency appeared larger than the scale } \\
\text { inefficiency. The banks from the MENA region dominated the } \\
\text { highest part of the efficiency frontier over the period of } \\
\text { analysis. A positive relationship was discovered across bank } \\
\text { efficiency and variables like loans intensity, size, } \\
\text { capitalization, and profitability through the use of Tobit } \\
\text { regression. }\end{array}$ \\
\hline $\begin{array}{l}\text { Sufian and Noor } \\
(2009)\end{array}$ & 2001-2006 & MENA & DEA & $\begin{array}{l}\text { The technical inefficiency appeared larger than the scale } \\
\text { inefficiency. The banks from the MENA region dominated the } \\
\text { highest part of the efficiency frontier over the period of } \\
\text { analysis. A positive relationship was discovered across bank } \\
\text { efficiency and variables like loans intensity, size, } \\
\text { capitalization, and profitability through the use of Tobit } \\
\text { regression. }\end{array}$ \\
\hline Akhtar (2013) & $2000-2009$ & $\begin{array}{l}\text { Saudi } \\
\text { Arabia }\end{array}$ & DEA & $\begin{array}{l}\text { The banks in KSA stood as least affected by the crisis of } 2007 \\
\text { and 2008. The average levels of inefficiency remained high } \\
\text { suggesting that KSA banks were laggards. Results of the Tobit } \\
\text { regression did reveal that the impact of financial crisis } \\
\text { remained weak and inconclusive. }\end{array}$ \\
\hline
\end{tabular}


Review of Economics and Development Studies, Vol. 6 (4) 2020, 739-758

\begin{tabular}{|c|c|c|c|c|}
\hline $\begin{array}{l}\text { Yayar and Karaca } \\
(2014)\end{array}$ & $2009-11$ & Turkey & $\begin{array}{l}\text { DEA and Tobit } \\
\text { regression }\end{array}$ & $\begin{array}{l}\text { The total assets and profitability variables were seen to have a } \\
\text { positive effect upon total efficiency scores. Variables like } \\
\text { capital adequacy ratio and number of branches had a negative } \\
\text { effect. }\end{array}$ \\
\hline $\begin{array}{l}\text { Hafez and Halim } \\
(2019)\end{array}$ & $2003-2017$ & Egypt & DEA & $\begin{array}{l}\text { The study has compared the efficiency scores of Islamic versus } \\
\text { conventional banks and found that Islamic banks are more } \\
\text { efficient. }\end{array}$ \\
\hline \multicolumn{5}{|c|}{ B) Studies on Financial Inclusion Index and Determinants } \\
\hline Honohan (2007) & 2007 & $\begin{array}{l}160 \\
\text { Countries }\end{array}$ & $\begin{array}{l}\text { Econometric } \\
\text { methodology }\end{array}$ & $\begin{array}{l}\text { The study has constructed estimates of fraction of households } \\
\text { with access to formal financial institutions. He used the ratio } \\
\text { of microfinance accounts and bank accounts to the total } \\
\text { population, household survey-based access and the average } \\
\text { deposit size and the per capita GDP. }\end{array}$ \\
\hline Ardic et al. (2011) & 2008-09 & $\begin{array}{l}46 \text { Selected } \\
\text { Countries }\end{array}$ & $\begin{array}{l}\text { Ordinary Least } \\
\text { Squares Method }\end{array}$ & $\begin{array}{l}\text { An important panel data study to find out the link between } \\
\text { access to financial services and FI in the World. The study } \\
\text { infers that there are } 56 \% \text { of adults who do not have bank } \\
\text { accounts. }\end{array}$ \\
\hline $\begin{array}{l}\text { Anzoategui et al. } \\
(2011)\end{array}$ & $\begin{array}{l}\text { 1996, } 1998 \\
2000, \quad \text { and } \\
2002 .\end{array}$ & El Salvador & Probit Estimation & $\begin{array}{l}\text { The results indicate variables like remittances, income/wealth } \\
\text { levels, education, returned migrants; other household features } \\
\text { (agriculture and electricity) have a positive impact on } \\
\text { financial inclusion. }\end{array}$ \\
\hline $\begin{array}{l}\text { Laha and Kuri } \\
\text { (2011) }\end{array}$ & $1999-2005$ & $\begin{array}{l}\text { West } \\
\text { Bengal, } \\
\text { India }\end{array}$ & $\begin{array}{l}\text { Binary Probit } \\
\text { regression } \\
\text { analysis }\end{array}$ & $\begin{array}{l}\text { This study has developed a composite index of FI and probed } \\
\text { the link between access to finance and FI in various states of } \\
\text { West Bengal. Using the Binary Probit regression model, the } \\
\text { study has pointed out various factors as obstacles related to } \\
\text { FI. }\end{array}$ \\
\hline $\begin{array}{l}\text { Akudugu } \\
(2013)\end{array}$ & 2012 & $\begin{array}{l}\text { Ghana } \\
\text { (Western } \\
\text { Africa) }\end{array}$ & Logit Estimation & $\begin{array}{l}\text { Gender (male), Age, literacy, cost, and family influence has } \\
\text { positive while distance, lack of documentation, lack of trust } \\
\text { and lack of money have negative association with financial } \\
\text { inclusion. }\end{array}$ \\
\hline
\end{tabular}


Review of Economics and Development Studies, Vol. 6 (4) 2020, 739-758

\begin{tabular}{|c|c|c|c|c|}
\hline $\begin{array}{l}\text { Chithra and Selvam } \\
(2013)\end{array}$ & $1992-2012$ & $\begin{array}{l}28 \text { Indian } \\
\text { States }\end{array}$ & $\begin{array}{l}\text { Ordinary Least } \\
\text { Squares Method }\end{array}$ & $\begin{array}{l}\text { This paper has investigated the determinants of FI for the } \\
\text { various states of India. The study has incorporated various } \\
\text { socio-economic factors as the factors determining FI. }\end{array}$ \\
\hline $\begin{array}{l}\text { Kumar } \\
(2013)\end{array}$ & $1995-2008$ & India & $\begin{array}{l}\text { Ordinary Least } \\
\text { Squares Method }\end{array}$ & $\begin{array}{l}\text { This study has also explored the factors of FI for different } \\
\text { Indian states. The study stresses more on economic } \\
\text { determinants for FI. The authors have suggested policies to } \\
\text { improve FI in India. }\end{array}$ \\
\hline $\begin{array}{l}\text { Tuesta et al. } \\
\text { (2015) }\end{array}$ & 2012 & Argentina & Probit Estimation & $\begin{array}{l}\text { This study explores the three aspects of FI for Argentina. The } \\
\text { study has analyzed FI from the micro economic point of view } \\
\text { by including access, use and barriers. }\end{array}$ \\
\hline $\begin{array}{l}\text { Clamara et al. } \\
(2014)\end{array}$ & 2012 & Peru & Probit Estimation & $\begin{array}{l}\text { The authors have used micro data to find out the factors of FI } \\
\text { in Peru with a focus on barriers to FI. }\end{array}$ \\
\hline $\begin{array}{l}\text { Tuesta } \\
(2014)\end{array}$ & 2012 & Mexico & $\begin{array}{l}\text { Multiple } \\
\text { Correspondence } \\
\text { Analysis }\end{array}$ & $\begin{array}{l}\text { The findings of the study show that Age, position in the } \\
\text { household, marital status, education, household behavior in } \\
\text { terms of savings, receipt of remittances, wage or salary, } \\
\text { financial infrastructure have positive relationship while } \\
\text { Locality with less than 15,ooo inhabitants has negative } \\
\text { relationship with financial inclusion. }\end{array}$ \\
\hline $\begin{array}{l}\text { Marr et al. } \\
(2014)\end{array}$ & 1981-2009 & Peru & $\begin{array}{l}\text { Ordinary Least } \\
\text { Squares Method }\end{array}$ & $\begin{array}{l}\text { The dummy variable of financial inclusion is total number of } \\
\text { newly-banked clients (TOTPERS), dummy variables of MFI } \\
\text { characteristics are level of MFI maturity (ANTIGUO) which } \\
\text { based on number of years of operation of the MFI since 20o8, } \\
\text { number of MFI branches (NSUC), total assets in millions of } \\
\text { Nuevos soles (ASSETS) and dummy variable of MFI strategic } \\
\text { relations is connection with Banco Nación (RBN9). TOTPERS } \\
\text { has positive relationship with NSUS, ASSETS and RBN9 while } \\
\text { it has negative association with ANTIGUO. }\end{array}$ \\
\hline
\end{tabular}


Review of Economics and Development Studies, Vol. 6 (4) 2020, 739-758

\begin{tabular}{|c|c|c|c|c|}
\hline $\begin{array}{l}\text { Park et al. } \\
(2015)\end{array}$ & $2004-2012$ & $\begin{array}{l}37 \quad \text { Asian } \\
\text { Developing } \\
\text { Countries }\end{array}$ & $\begin{array}{l}\text { Ordinary Least } \\
\text { Squares Method }\end{array}$ & $\begin{array}{l}\text { The results of the study show that rule of law, PCI and } \\
\text { demographic variables have significant effect on FI. The } \\
\text { negative relationship between FI and poverty has been } \\
\text { observed. Further the study has pointed out a positive } \\
\text { association between demographic variables and FI. }\end{array}$ \\
\hline Naceur et. al (2015) & $2004-13$ & $\begin{array}{l}\text { OIC } \\
\text { countries }\end{array}$ & $\begin{array}{l}\text { Regression } \\
\text { analysis }\end{array}$ & $\begin{array}{l}\text { The authors discovered that even though the physical access } \\
\text { to financial services has grown more rapidly in the OIC } \\
\text { countries, the use of such services has not grown at that } \\
\text { speed. Results of the regression analysis reveal the existence } \\
\text { of a positive link on credit to households and to firms for } \\
\text { financing their investments. However, the empirical link } \\
\text { remains uncertain and relatively weak. }\end{array}$ \\
\hline $\begin{array}{l}\text { Zins and Weill } \\
(2016)\end{array}$ & 2014 & $\begin{array}{l}37 \quad \text { Africa } \\
\text { Countries }\end{array}$ & Probit Estimation & $\begin{array}{l}\text { The study has computed determinants of financial inclusion } \\
\text { indicators i.e., female, age, income and education. Female and } \\
\text { income have negative association while age and education } \\
\text { have positive relationship with FI. Moreover, the authors have } \\
\text { also calculated the factors related to barriers to financial } \\
\text { inclusion and mobile money banking. }\end{array}$ \\
\hline Abdu et al. (2018) & 2014 & $\begin{array}{l}\text { Sub-Sahara } \\
\text { Africa }\end{array}$ & $\begin{array}{l}\text { Probit, Tobit and } \\
\text { Juhn-Murphy- } \\
\text { Pierce } \\
\text { decomposition }\end{array}$ & $\begin{array}{l}\text { The study supports the fact that Islamic banking has spurred } \\
\text { the financial inclusion. }\end{array}$ \\
\hline $\begin{array}{l}\text { Akhtera } \\
(2019)\end{array}$ & $2005-2014$ & $\begin{array}{l}28 \\
\text { countries of } \\
\text { Asia and } \\
\text { Africa }\end{array}$ & Panel Regression & $\begin{array}{l}\text { This study has focused on role of Islamic banking by } \\
\text { considering demand and supply side factors of financial } \\
\text { inclusion. The findings suggest that Islamic banking is playing } \\
\text { a vital role in enhancing financial inclusion through the } \\
\text { demand side dimension. }\end{array}$ \\
\hline $\begin{array}{l}\text { Kabiru \& Ibrahim } \\
(2020)\end{array}$ & $2013-2018$ & $\begin{array}{l}\text { OIC } \\
\text { Countries }\end{array}$ & $\begin{array}{l}\text { GMM, Second- } \\
\text { generation } \\
\text { cointegration and } \\
\text { causality test }\end{array}$ & $\begin{array}{l}\text { The authors have pointed out that Islamic banking is } \\
\text { promoting financial inclusion in OIC countries. However, no } \\
\text { bi-directional causality has been found between Islamic } \\
\text { banking and financial inclusion. }\end{array}$ \\
\hline
\end{tabular}




\section{Construction of Financial Inclusion Index}

The financial inclusion index as reflected in Table 2 has emerged as a result of detailed process starting from the identification of three dimensions of financial inclusion. These dimensions were based on the usage of financial services (D1), access to these services (D2) and quality of products and services delivery (D3). Each dimension was further explained through some indicators where D1 is represented by four, D2 by eight and D3 by two indicators. The descriptive statistics for indicators of three dimensions are produced in Table A1 in the appendix. The construction of FII with three dimensions and their indicators are elaborated through Figure 1.

\section{Figure 1: Components of Financial Inclusion Index}

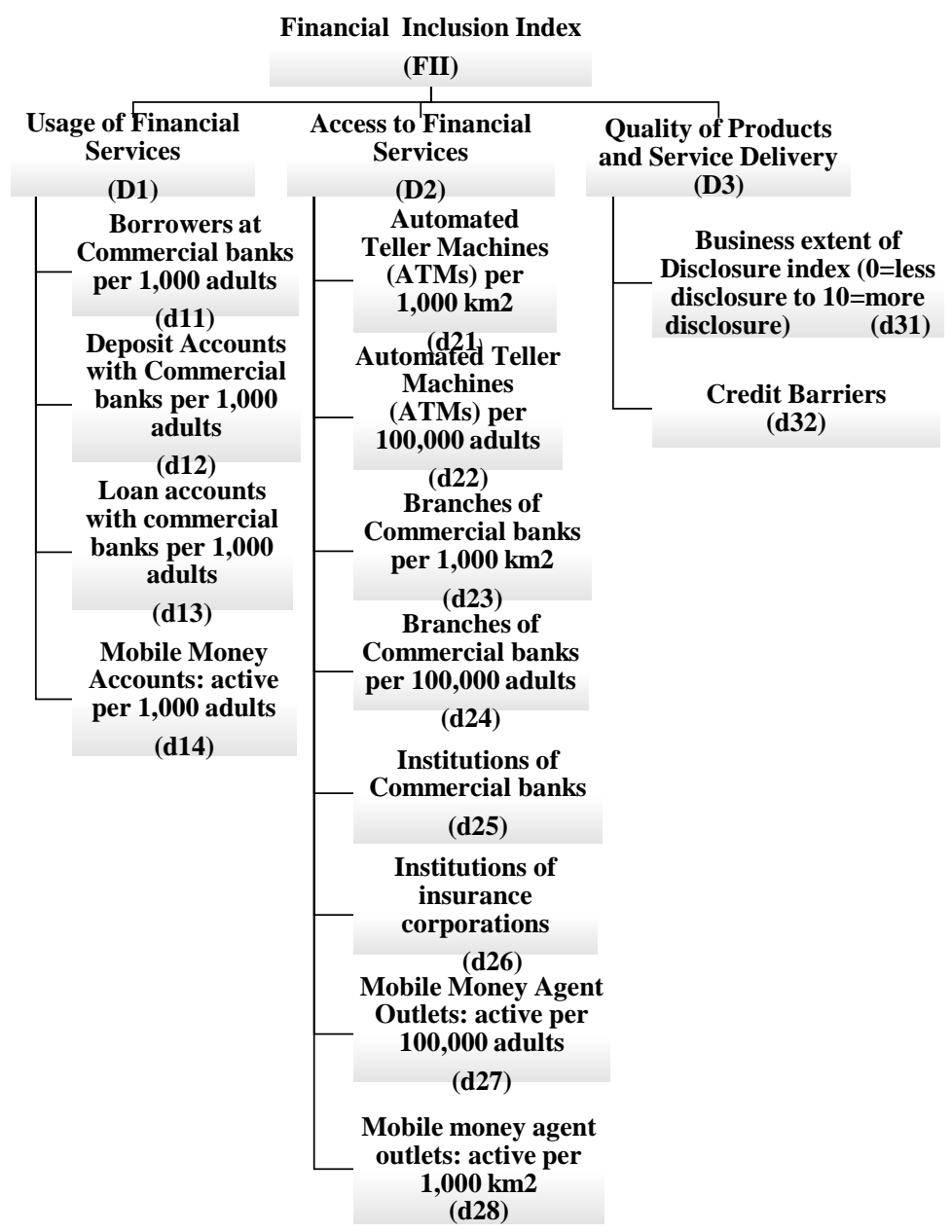

Source: Authors' own elaborations

For each dimension of financial inclusion, a dimension index $\mathrm{Di}$, is calculated as shown in table-A2, through the formula below.

$$
\mathrm{d}_{i}=\frac{\mathrm{X}_{A d}-X_{\min d}}{X_{\max d}-X_{\min d}}
$$


Where:

$\mathrm{d}_{i}=$ Dimenssions of Financial Inclusion $\mathrm{d}$.

$\mathrm{X}_{A d}=$ Actual value of dimenssion $\mathrm{d}$

$X_{\min d}=$ Minimum value of dimenssion $\mathrm{d}$

$X_{\min d}=$ Maximum value of dimenssion $\mathrm{d}$

On the next step, the values of $\mathrm{X} 1$ and $\mathrm{X} 2$ are derived with the formulae given in equations 2 and 3. $\mathrm{X} 1$ represents the average of the Euclidian distance between o and $\mathrm{X}$ where a higher value of $\mathrm{X}_{1}$ stands for high level of financial inclusion and vice versa while the X2 inverse Euclidian distance between $\mathrm{X}$ and $\mathrm{W}$, indicated by the equation 3 for FII.

$$
\begin{gathered}
X_{1}=\frac{\sqrt{d_{1}^{2}+d_{2}^{2}+d_{3}^{2}+\ldots . .+d_{n}^{2}}}{\sqrt{\mathrm{w}_{1}^{2}+\mathrm{w}_{2}^{2}+\mathrm{w}_{3}^{2}+\ldots . .+\mathrm{w}_{\mathrm{n}}^{2}}} \\
\mathrm{X}_{2}=1-\left[\frac{\sqrt{\left(1-\mathrm{d}_{1}\right)^{2}+\left(1-\mathrm{d}_{2}\right)^{2}+\left(1-\mathrm{d}_{3}\right)^{2}+\ldots . .+\left(1-\mathrm{d}_{\mathrm{n}}\right)^{2}}}{\sqrt{\mathrm{w}_{1}^{2}+\mathrm{w}_{2}^{2}+\mathrm{w}_{3}^{2}+\ldots . .+\mathrm{w}_{\mathrm{n}}^{2}}}\right] \\
F I I=\frac{1}{2}\left[\mathrm{X}_{1}+\mathrm{X}_{2}\right]
\end{gathered}
$$

Equation 4 computes the mean of and given the values of FII, the levels of financial inclusion are reflected by the ranges given below (Goel and Sharma, 2017):

- $\quad 0 \leq$ FII $\leq$ o.4; (low financial inclusion)

- $0.4<$ FII $\leq$ o.6; (medium financial inclusion)

\begin{tabular}{|c|c|c|c|c|c|}
\hline Years & $\mathrm{X} 1$ & $\mathrm{X} 2$ & FII & FII Range & Conclusion \\
\hline 2007 & 0.5443 & 0.1703 & 0.3573 & \multirow{6}{*}{$\mathrm{O} \leq \mathrm{FII} \leq 0.4$} & \multirow{6}{*}{ LFI } \\
\hline 2008 & 0.5128 & 0.2298 & 0.3713 & & \\
\hline 2009 & 0.5029 & 0.2794 & 0.3911 & & \\
\hline 2010 & 0.4736 & 0.2962 & 0.3849 & & \\
\hline 2011 & 0.4657 & 0.3115 & 0.3886 & & \\
\hline 2012 & 0.3665 & 0.2891 & 0.3278 & & \\
\hline 2013 & 0.5181 & 0.3953 & 0.4567 & \multirow{3}{*}{$\begin{array}{c}0.4<\text { FII } \leq \\
0.6\end{array}$} & \multirow{3}{*}{ MFI } \\
\hline 2014 & 0.5706 & 0.3940 & 0.4823 & & \\
\hline 2015 & 0.7185 & 0.4449 & 0.5817 & & \\
\hline 2016 & 0.7905 & 0.4641 & 0.6273 & $0.6<$ FII $\leq 1$ & HFI \\
\hline
\end{tabular}

- $0.6<$ FII $\leq 1$; (high financial inclusion)

Table 2: Values of Financial Inclusion Index

Note: LFI, MFI and HFI stands for Low Financial Inclusion, Medium Financial Inclusion and High Financial Inclusion respectively.

Source: Authors' calculations 
The results of Table 2 reveal that Financial Inclusion in Pakistan has increased gradually over the period from 2007 to 2016. From 2007 to 2012, Pakistan can be seen in low level of financial inclusion as the index ranges from o to 0.4. However, the level of FII stands at 0.5 to o.6 showing the medium level of FI during the years 2013 to 2015. In the year 2016, Pakistan seems to have entered the club of high financial inclusion as the index has gone up to o.63. This might have been the result of National Financial Inclusion Strategy launched by the government of Pakistan during the recent years.

\section{Technical Efficiency Analysis}

The study is based on a population analysis of all the commercial banks ${ }^{1}$ operating in Pakistan during the period of 2007 to 2016. Data for the study was extracted through the Banking Statistics of Pakistan provided by the State Bank of Pakistan (SBP). The model used in the study is based on two inputs and two outputs where the inputs are: (i) deposits and (ii) administrative expenses while the outputs are: (i) loans \& advances and (ii) investments. Hence, the model estimates the efficiency of commercial banks in transforming input quantities into amounts of output. The $2 \times 2$ model fulfills the DEA concord as the minimum number of decision-making units (DMUs) is greater than three times the number of inputs plus outputs (Dyson et al., 2001). The flow of services provided by banks can be measured through either the production approach or the intermediation approach. The intermediary role tends to be a by-product of the production function of banks. By the same notion, the study assumes intermediation approach where financial institutions are considered as the entities that could convert inputs like deposits into outputs such as advances and investments.

The input and output variables were mainly selected in context of the existing theoretical strands and the extant literature. Banks tend to generate their input resources mainly through deposits which enable them to carry on their lending and investment in the economy. Unlike other businesses, bank expenditures determine to what extent banks are cost efficient. For this reason, administrative expenses are used as the second input. Table-A3 exhibits descriptive statistics for variables used as inputs and outputs in the study.

Studies on the efficiency analysis of commercial banks have mainly used frontier methodologies e.g. econometric frontier analysis and the data envelopment analysis (DEA), both with their own merits and demerits2. The DEA allows the use of multiple inputs and outputs without inflicting any functional form on the data and making any distributional assumptions on the inefficiency term.

Technical efficiency (TE) is essential in measuring the bank performance. It reflects the degree of production efficiency and innovation. Based on the DEA model, technical efficiency scores of each bank in terms of constant returns to scale (CRS) and variable returns to scale (VRS) are reflected in Table 3 for the period 2007-2016. The efficiency scores presented in Table 3 reveal that only one of the Islamic banks appeared to be VRS efficient during the period of analysis. Among the conventional banks, only four of the banks appear to be technically efficient both on CRS and VRS grounds during the whole period with four others being VRS efficient only. Four of the banks that have emerged as both technically CRS and VRS efficient are smaller banks. This refers to the fact that small size banks are better to achieve high technical efficiency levels rather than the larger banks which do not seem to be managing well in terms of their production efficiency due to their large size.

1 As on 31st December 2016, there stood 35 commercial banks in Pakistan (SBP, 2016). However, four of the commercial banks were specialized banks while out of the remaining 31 banks, consistent data could only be found for 24 banks for the period of analysis.

2 For details on the advantages and disadvantages of DEA, see Akhtar (2010). 
Review of Economics and Development Studies, Vol. 6 (4) 2020, 739-758

Table 3: Technical Efficiency Scores of Banks under CRS \& VRS and Scale Efficiency (2007-2016)

\begin{tabular}{|c|c|c|c|c|c|}
\hline DMU & Banks & $\begin{array}{c}\text { CRS } \\
\text { Technical } \\
\text { Efficiency } \\
\end{array}$ & $\begin{array}{c}\text { VRS } \\
\text { Technical } \\
\text { Efficiency }\end{array}$ & $\begin{array}{c}\text { Scale } \\
\text { Efficiency }\end{array}$ & Remarks \\
\hline \multicolumn{6}{|c|}{ Islamic Bank } \\
\hline 1 & Dubai Islamic Bank Pakistan Ltd. & 0.823 & 0.828 & 0.994 & IRS \\
\hline 2 & Meezan Bank Ltd. & 0.74 & 0.741 & 0.999 & IRS \\
\hline 3 & Bank Islami Pakistan Ltd. & 0.681 & 0.757 & 0.899 & IRS \\
\hline 4 & Albaraka Bank (Pakistan) Ltd. & 0.874 & 1 & 0.874 & IRS \\
\hline & Average Scores & 0.7795 & 0.8315 & 0.9415 & \\
\hline \multicolumn{6}{|c|}{ Conventional Banks } \\
\hline 5 & Allied Bank Ltd. & 0.801 & 0.834 & 0.96 & DRS \\
\hline 6 & Askari Bank Ltd. & 0.824 & 0.849 & 0.971 & DRS \\
\hline 7 & Bank Alfalah Ltd. & 0.752 & 0.827 & 0.909 & DRS \\
\hline 8 & Bank Al-Habib Ltd. & 0.825 & 0.837 & 0.985 & DRS \\
\hline 9 & Faysal Bank Ltd. & 1 & 1 & 1 & - \\
\hline 10 & First Women Bank Ltd. & 0.731 & 1 & 0.731 & IRS \\
\hline 11 & Habib Bank Ltd. & 0.843 & 1 & 0.843 & DRS \\
\hline 12 & Habib Metropolitan Bank Ltd. & 1 & 1 & 1 & - \\
\hline 13 & JS Bank Ltd. & 0.807 & 0.822 & 0.981 & DRS \\
\hline 14 & MCB Bank Ltd. & 0.986 & 1 & 0.986 & DRS \\
\hline 15 & National Bank of Pakistan & 0.736 & 1 & 0.736 & DRS \\
\hline 16 & NIB Bank Ltd. & 0.923 & 0.926 & 0.998 & IRS \\
\hline 17 & Silk Bank Limited & 0.778 & 0.806 & 0.966 & DRS \\
\hline 18 & Soneri Bank Ltd. & 0.848 & 0.86 & 0.986 & IRS \\
\hline 19 & $\begin{array}{l}\text { Standard Chartered Bank } \\
\text { (Pakistan) Ltd. }\end{array}$ & 0.788 & 0.831 & 0.949 & DRS \\
\hline 20 & Summit Bank Ltd. & 1 & 1 & 1 & - \\
\hline 21 & The Bank of Khyber & 0.79 & 0.917 & 0.862 & IRS \\
\hline 22 & The Bank of Punjab & 1 & 1 & 1 & - \\
\hline 23 & United Bank Ltd. & 0.876 & 1 & 0.876 & DRS \\
\hline \multirow[t]{2}{*}{24} & Samba Bank Ltd. & 0.546 & 0.567 & 0.963 & IRS \\
\hline & Average Scores & 0.8427 & 0.9038 & 0.9351 & \\
\hline
\end{tabular}

Source: Authors' calculations

Looking at the performance of Islamic vis-à-vis conventional banks, it can be observed that the average efficiency scores of Islamic banks are lower than those of their conventional counterparts both on CRS and VRS terms but are nearly identical in terms of scale efficiency. However, Islamic banks tend to be operating under the increasing returns to scale (IRS) where doubling of inputs more than doubles the output. On the contrary, majority of the conventional banks appear to be operating under the DRS where doubling of inputs less than doubles the output. This reveals that Islamic banks have the potential to perform better than their conventional peers. 


\section{Econometric Analysis}

Having calculated the FII and TE, our next task is to link these by formulating two econometric models. The first model explains the impact of Islamic banks on financial inclusion while the second model points out the link between financial inclusion and technical efficiency. This is to confirm the fact whether FI and bank efficiency reinforce each other or not? Following are the econometric forms of the both the models:

Model 1: Islamic banks and Financial Inclusion

$$
F I I=\alpha_{0}+\alpha_{1} G D P P C+\alpha_{2} U R B G+\alpha_{3} D G+\varepsilon
$$

Model 2: Financial Inclusion and Technical Efficiency

$$
T E=\beta_{0}+\beta_{1} F I I+\beta_{2} R O E+\beta_{3} T R A D E+\varepsilon
$$

Where:

FII $=$ Financial Inclusion Index

GDPPC $=$ GDP per capita growth (annual \%)

$\mathrm{URBG}=$ Urban population (\% of total population) Growth Rate

DG = Deposits Growth Rate of Islamic Banks

$\mathrm{TE}=$ Technical Efficiency

ROE = Returns on Equity

TRADE $=$ Trade $(\%$ of GDP $)$

An annual time series data from 2007 to 2016 have been selected for this study. The data on various dimensions of FII have been taken from WB Global Findex, IMF Financial Access Surveys, WB Global Consumer Protection Survey and WBG Doing Business while data on macroeconomic variables i.e. GDPPC, URBG, TRADE have been acquired from World Development Indicators (WDI). The bankspecific data on ROE, Investments, advances, administrative expenditures, and deposits have been attained from Handbook of Statistics on Pakistan economy, a flagship publication of State Bank of Pakistan. The methodology applied is Autoregressive Distributed Lag (ARDL) technique. The ARDL specification of the equations 5 and 6 are given as:

$$
\begin{aligned}
& \Delta(F I I)_{t}=\alpha+\beta_{1}(G D P P C)_{t-1}+\beta_{2}(U R B G)_{t-1}+\beta_{3}(D G)_{t-1}+\sum_{i=1}^{z_{1}} \phi_{1} \Delta(F I I)_{t-i}+\sum_{i=0}^{z_{2}} \phi_{2} \Delta(G D P P C)_{t-i} \\
& +\sum_{i=0}^{z_{3}} \phi_{3} \Delta(U R B G)_{t-i}+\sum_{i=0}^{z_{4}} \phi_{4} \Delta(D G)_{t-i}+\varepsilon_{t} \\
& \Delta(T E)_{t}=\alpha+\beta_{1}(F I I)_{t-1}+\beta_{2}(R O E)_{t-1}+\beta_{3}(T R A D E)_{t-1}+\sum_{i=1}^{z_{1}} \phi_{1} \Delta(T E)_{t-i}+\sum_{i=0}^{z_{2}} \phi_{2} \Delta(F I I)_{t-i} \\
& +\sum_{i=0}^{z_{3}} \phi_{3} \Delta(R O E)_{t-i}+\sum_{i=0}^{z_{4}} \phi_{4} \Delta(T R A D E)_{t-i}+\varepsilon_{t}
\end{aligned}
$$

It is imperative to test for the stationarity of data to avoid the spurious regression. To reach this end, ADF unit root test of stationarity has been applied. 
Review of Economics and Development Studies, Vol. 6 (4) 2020, 739-758

Table 4: Results of ADF Unit Root Test

\begin{tabular}{|c|c|c|c|c|c|c|c|}
\hline \multicolumn{8}{|c|}{ ADF Test at Level } \\
\hline Variables & Intercept & Lags & $\begin{array}{c}\text { Intercept } \\
\text { and } \\
\text { Trend } \\
\end{array}$ & Lags & None & Lags & Conclusion \\
\hline FII & $\begin{array}{c}0.292650 \\
(0.9617)\end{array}$ & $\mathrm{O}$ & $\begin{array}{c}-1.061389 \\
(0.8738) \\
\end{array}$ & $\mathrm{O}$ & $\begin{array}{l}1.634769 \\
(0.9625) \\
\end{array}$ & $\mathrm{O}$ & $\mathrm{I}(1)$ \\
\hline $\mathrm{TE}$ & $\begin{array}{c}-1.463281 \\
(0.5049) \\
\end{array}$ & $\mathrm{O}$ & $\begin{array}{r}-1.212644 \\
(0.8383) \\
\end{array}$ & $\mathrm{O}$ & $\begin{array}{c}-0.437193 \\
(0.4956) \\
\end{array}$ & $\mathrm{O}$ & $\mathrm{I}(1)$ \\
\hline GDPPC & $\begin{array}{l}1.216918 \\
(0.9936)\end{array}$ & 1 & $\begin{array}{c}- \\
3.410902 \\
(0.1240)\end{array}$ & 1 & $\begin{array}{c}3.084109 \\
(0.9960)\end{array}$ & 1 & $\mathrm{I}(1)$ \\
\hline ROE & $\begin{array}{l}-2.249411 \\
(0.2055)\end{array}$ & 1 & $\begin{array}{c}- \\
4.023576 \\
(0.0635)\end{array}$ & 1 & $\begin{array}{c}- \\
0.524308 \\
(0.4610) \\
\end{array}$ & $\mathrm{O}$ & $\mathrm{I}(1)$ \\
\hline URBG & $\begin{array}{c}- \\
0.677364 \\
(0.7969) \\
\end{array}$ & 1 & $\begin{array}{c}-13.28737 \\
(0.0001)\end{array}$ & $\mathrm{O}$ & $\begin{array}{c}- \\
5.620590 \\
(0.0002) \\
\end{array}$ & 1 & $\mathrm{I}(\mathrm{O})$ \\
\hline DG & $\begin{array}{c}- \\
1.659327 \\
(0.4166) \\
\end{array}$ & $\mathrm{O}$ & $\begin{array}{c}- \\
3.502680 \\
(0.1020) \\
\end{array}$ & $\mathrm{O}$ & $\begin{array}{c}- \\
1.603348 \\
(0.0993) \\
\end{array}$ & 1 & $\mathrm{I}(\mathrm{O})$ \\
\hline TRADE & $\begin{array}{c}-27.15092 \\
(0.0001)\end{array}$ & 1 & $\begin{array}{c}-251.8337 \\
(0.0001)\end{array}$ & 1 & $\begin{array}{c}-1.258012 \\
(0.1751)\end{array}$ & 1 & $\mathrm{I}(\mathrm{O})$ \\
\hline
\end{tabular}

Source: Authors' calculations

Table 4 demonstrates results of ADF test at level. The two dependent variables i.e. FII and TE are non-stationary (having unit root) at level. The explanatory variables namely GDPPC and ROE have unit root (non-stationary) and URBG and TRADE are stationary (no unit root). It can be deduced from Table 6 that all the variables have mixed order of integration so the appropriate technique to estimate the equations 7 and 8 would be Autoregressive Distributed Lag (ARDL) approach to cointegration.

The first step of the ARDL is to detect the existence of cointegration based on values of Fstatistics. The values of F-statistics are compared to the critical values of the bounds. The results of FTest are displayed in Table 5 .

Table 5: F-Test for Cointegration

\begin{tabular}{|l|c|c|c|c|c|}
\hline \multicolumn{2}{|c|}{} & \multicolumn{2}{c|}{$5 \%$ Critical Value Bounds } & \multicolumn{2}{c|}{ 10\% Critical value Bounds } \\
\hline & F-Statistic & $\mathrm{I}(\mathrm{O})$ & $\mathrm{I}(1)$ & $\mathrm{I}(\mathrm{O})$ & $\mathrm{I}(1)$ \\
\hline Model 1 & 7.59 & 3.23 & 4.35 & 2.72 & 3.77 \\
\hline Model 2 & 4.85 & 3.23 & 4.35 & 2.72 & 3.77 \\
\hline
\end{tabular}

Source: Authors' calculations

The results of the $\mathrm{F}$ test allude towards rejection of the null hypothesis of no cointegration in both the models since the calculated F-statistics are more than the upper bounds at 5percent and 10 
percent levels of significance. The calculated F-statistics are 7.59 and 4.85 that are more than upper bounds values of 4.35 and 3.77 in model 1 and model 2 respectively. Bounds test reveals that cointegration exists which allows us to proceed to the next step by computing the long-run estimates of both the models.

Table 6 presents the long-run estimates of both the models. In the first model of Islamic banks and Financial Inclusion, the regressand is financial inclusion index (FII) and regressors are GDP per capita growth rate (GDPPC), urban population Growth Rate (URBG), and deposits Growth Rate of Islamic Banks (DG).

Table 6: Long-Run Estimates of Model 1 \& 2

\begin{tabular}{|c|c|c|c|c|c|}
\hline \multicolumn{3}{|c|}{ Model 1 } & \multicolumn{3}{c|}{ Model 2 } \\
\hline \multicolumn{3}{|c|}{$\begin{array}{c}\text { Dependent Variable: FII } \\
\text { Selected Model: ARDL }(1,1,1)\end{array}$} & \multicolumn{3}{c|}{$\begin{array}{c}\text { Dependent Variable: TE } \\
\text { Selected Model: ARDL }(1,1,1,0)\end{array}$} \\
\hline Variables & Coefficient & Prob. & Variables & Coefficient & Prob. \\
\hline GDPPC & 0.095663 & 0.0224 & FII & 3.569597 & 0.0203 \\
\hline URBG & 0.942307 & 0.0833 & ROE & -0.822794 & 0.0264 \\
\hline DG & 0.260075 & 0.0354 & TRADE & 0.160179 & 0.0869 \\
\hline C & -2.643771 & 0.0860 & C & -4.985900 & 0.0975 \\
\hline
\end{tabular}

Source: Author's calculations

The GDP per capita is a proxy for economic growth. There are two views about the financial development3 and economic growth: supply side4 and demand side. The demand-pulling hypothesis suggests that economic growth spurs the financial development (Robinson,1952; Friedman and Schwartz,1963). The sign of the parameter of GDPPC is positive and statistically highly significant. The positive sign can be validated towards the demand-pulling hypothesis which explains that as an economy grows, the demand for financial products increases. In other words, usage of financial services; access to financial services; the quality of the financial products and the service delivery recuperate due to the economic growth and advancement. Thus, the financial system would be more inclusive as economy achieves higher economic growth (Evans, 2015). Our results are consistent with those by Halicioglu, 2007, Sarma and Pais, 2011, Chithra and Selvam, 2013, Camara et al., 2014, Fungáčová and Weill, 2015, Tuesta et al., 2015 and Oyelami, et al. 2017.

Financial system stands as alpha and omega in an economy which mobilizes the resources from surplus to deficit units. Economic theory suggests that urbanization and FI are positively associated as the people in urban areas have greater access and usage of financial services delivery; it results in high level of financial inclusion. The parameter of urbanization appears with the positive sign in our model as expected5. It suggests that urbanization is fostering financial inclusion in Pakistan. Urbanization in Pakistan has increased from 37 percent to almost 40 percent in 2016 (GOP, 2016). The positive association between urbanization and financial inclusion may be supported by the fact that an

3 Financial inclusion is a part of financial development.

4 The seminal study by Patrick (1966) has proposed two competing hypotheses: i) The supply-leading hypothesis and ii) demand-pulling hypothesis. We have not investigated supply leading hypothesis that explains the impact of financial development and economic growth meaning that as financial development occurs in the economy, it escalates savings, capital accumulation, and investment results in economic growth. Goldsmith (1969), McKinnon (1973) and Shaw (1973) also proved the supply-leading hypothesis.

5 The study by Lyons, et al., (2017) supports the negative link between urbanization and financial inclusion. 


\section{Review of Economics and Development Studies, Vol. 6 (4) 2020, 739-758}

increasing number of people tend to migrate from rural areas to urban areas for various reasons including high earnings, employment, education, health and various infrastructural facilities. Having moving to urban areas, they can use more financial products through the channels of education, confidence, and banking habits. The finding are supported by Marr et al., 2014; Naceur et al.,2015.

The last regressor in the model is deposits growth rate of Islamic banks (DG). This stands as the core variable in our reinforcement analysis. We have used the proxy of deposits growth rate of Islamic banks to probe the impact of Islamic banks on financial inclusion. The parameter is positively significant confirming role of Islamic banks towards financial inclusion. As an Islamic country, people are more inclined towards the Islamic financial institutions. Hence, religiosity factor seems to be dominant and contributing to escalating the financial inclusion as the Muslims feel tilted towards the use of Shariah-compliant products. They have no fear of 'Riba' as all the Islamic modes of finance are according to 'Shariah'. Our findings are compatible with those by Demirguc-Kunt, et al., 2014; Naceur, et al., 2015 and Shaikh et al., 2017.

Moving forward to model 2 where the responding variable is technical efficiency (TE) while the explanatory variables are Financial Inclusion Index (FII), Returns on Equity (ROE), and Trade as a percentage of GDP (TRADE). The first parameter is Financial Inclusion Index which shows the positive association with the technical efficiency of the banks in Pakistan. This result can be justified on the following grounds. Financial inclusion is a multidimensional phenomenon that accelerates the efficiency of banks as the financial inclusion ensues in any economy; it enhances the provision of formal financial products to community at large regardless of their financial status. At higher levels of FI taking the form of financial literacy and capability, numbers of borrowers, deposit accounts, loan accounts, branches, automated teller machines (ATMs), insurance corporations, mobile money accounts, mobile money agent outlets, the efficiency of financial sector particularly commercial banks escalates. This in turn boosts the technical efficiency along with the quality of financial products and service delivery. The results are consistent with the findings by Jemric and Vujcic, 2002 and Chauvet and Jacolin, 2017.

Return on Equity (ROE) is a bank-specific variable. This as a measure of profitability appears with a significantly negative relationship with the TE. The result reveals that profitability and efficiency do not go in tandem. This reinforces that the efficiency and profitability are independent of each other by the banks in Pakistan. These results are in line with the findings by Akhtar (2013) and Abbasoglu et al. (2007) but are contrary to the findings of Jackson and Fethi (2000), Hassan (2006) and Sufian and Mohamad Noor (2009). TRADE, being a macroeconomic variable is used as the proxy for trade liberalization and globalization. The sign of TRADE is positive and statistically significant. The financial sector is an important contributory and beneficiary of international trade. Both financial and trade sectors stimulate each other, reinforcing the importance of FI. Due to fewer restrictions on international trade and with more globalization of goods and services, the volume of trade has increased where the monetary and financial transactions would take place through the financial sector. Therefore, the banks would improve themselves at par with the other international financial institutions and resultantly, the efficiency of the banking sector would also escalate.

The results of Error Correction Estimates of Model 1 and 2 are displayed in Table 7. The error correction terms in both the models are negative and statistically significant. The error correction term shows the speed of adjustment towards equilibrium. The values of error correction terms in both the models are -1.37 and -1.34 respectively implying that almost one and half years are required to restore the equilibrium. 
Review of Economics and Development Studies, Vol. 6 (4) 2020, 739-758

Table 7: Error Correction Estimates of Models 1 \& 2.

\begin{tabular}{|c|c|c|c|c|c|}
\hline \multicolumn{3}{|c|}{ Model 1 } & \multicolumn{3}{c|}{ Model 2 } \\
\hline \multicolumn{2}{|c|}{ Selected Model: ARDL $(1,1,1,1)$} & \multicolumn{2}{c|}{ Selected Model: ARDL (1, 1, 1, o) } \\
\hline Variables & Coefficient & Prob. & Variables & Coefficient & Prob. \\
\hline D(GDPPC) & 0.093167 & 0.0191 & D(FII) & 2.478185 & 0.0949 \\
\hline D(URBG) & -2.674766 & 0.0315 & D(ROE) & -0.052270 & 0.1153 \\
\hline D(DG) & 0.113216 & 0.0727 & D(TRADE) & 0.214797 & 0.1153 \\
\hline CointEq(-1) & -1.377408 & 0.0145 & CointEq(-1) & -1.340983 & 0.0320 \\
\hline
\end{tabular}

Source: Authors' calculations

\section{Conclusions and Policy Implications}

The study emerges as forerunner towards estimating the role of whole population of banks including Islamic banks in Pakistan towards financial inclusion for a significant period. The empirical findings allude towards a possible relationship between Islamic banking and financial inclusion, measured through various dimensions with different indicators for each. Hence, the study stands as novel in terms of developing a broad-based index of financial inclusion for Pakistan over a period of 10 years. This facilitates to track the developments on FI front in Pakistan over the period. By entering the high financial inclusion range, Pakistan might enjoy the fruits of inclusive growth along with an improvement in living styles and investment behavior of the masses. The data analysis for a period of 10 years can be considered as fully representative of population of banks in Pakistan along with their Islamic counterparts. The study offers a variety of useful policy implications for public policy towards effective progress on the NFIS in the country as well as bank managers of Islamic banks.

Firstly, although Islamic banks appear to be operating under the IRS yet only one of the banks appears to be efficient. This needs to be improved by utilizing their inputs optimally. Secondly, the banks need to pursue actions that might enable them to become efficient by taking advantage of their specialized Shariah-compliant products. Thirdly, as per growth trajectory of FI in Pakistan, there is a need to improve further by taking measures that could reduce the degree of financial exclusion in the country. This can take place through the growth in per capita GDP, urbanization as well as growth in Islamic banking across the country. Fourthly, since the Islamic banking does contribute towards FI, the latter also is seen as contributing towards making banks efficient. Hence, it supports the notion that Islamic banks and financial inclusion reinforce each other. Fifthly, the operational modalities of Islamic banking need to be strengthened in a way that could create awareness about various products of Islamic banks like Murabaha, Ijarah, Istisna'a and Salam etc. In this regard, the Islamic banks could establish loan units that could finance the needs of small businesses on Shariah-compliant basis. Sixthly, there is a dire need to magnify both the credit base and client base to promote FI in Pakistan. This can be achieved by reducing the information asymmetries prevalent in the market as these tend to reduce the expected benefits from the development of banking systems (Chauvet and Jacolin, 2017). Lastly, there stands a need to strengthen financial infrastructure and regulatory frameworks in the country to augment financial inclusion.

In context of the implications and results discussed above, it can be inferred that the study provides a starting point about financial inclusion status of Pakistan as reflected through the index of FI. Future research can be conducted on the determinants of FI in Pakistan and to evaluate the impact 
of National Financial Inclusion Strategy that can support growth process of Pakistan economy.

\section{References}

Abdu, M., Jibir, A., Abdullahi, S., \& Rabi'u, A. A. (2018). Can Islamic banking and finance spur financial inclusion? Evidence from Sub-Saharan Africa. CBN Journal of Applied Statistics, 9(1), 77-104.

Akhtar, M. H, (2010). Are Saudi banks productive and efficient? International Journal of Islamic and Middle Eastern Finance and Management 10(2), 95-112.

Akhtar, M. H, (2013). After the financial crisis: a cost efficiency analysis of banks from Saudi Arabia, International Journal of Islamic and Middle Eastern Finance and Management 6(4), 322-332.

Akhtera, W., Majeedb, M. U., \& Roubaudc, D. (2019). Islamic Banking and Financial Inclusion: Evidence from Asian and African Markets. Journal of Islamic Business and Management, $9(2), 341-354$.

Akudugu, M. A, (2013). The determinants of financial inclusion in Western Africa: insights from Ghana. Research Journal of Finance and Accounting 4(8),1-9.

Al-Muharrami, S, (2008). An examination of technical, pure technical and scale efficiencies in GCC banking, American Journal of Finance and Accounting 1(2), 152-66.

Anzoategui, D. Demirgüç-Kunt, A. \& Pería, M. S. M, (2014). Remittances and financial inclusion: evidence from El Salvador, World Development 54, 338-349.

Ardic, O., Heimann, M., \& Mylenko, N, (2011). Access to financial services and the financial inclusion agenda around the world: a cross-country analysis with a new data set, Policy Research Working Paper 5537.

Babajide, A. A. Adegboye, F. B. \& Omankhanlen, A. E, (2015). Financial inclusion and economic growth in Nigeria, International Journal of Economics and Financial Issues 5(3), 629-637.

Beck, T., Buyukkarabacak, B., Rioja, F. K. and Valev, N. T, (2012). Who gets the credit? And does it matter? Household vs firm lending across countries, The BE Journal of Macroeconomics 12(1), 1-46.

Ben Naceur, S., Barajas, A., \& Massara, A, (2015). Can Islamic Banking Increase Financial Inclusion? IMF Working Paper No. 31.

Camara, N. \& Tuesta, D, (2015). Factors that matter for financial inclusion: Evidence from Peru. Aestimatio Working Paper No.10.

Chauvet, Lisa and Luc Jacolin, (2017). Financial Inclusion, Bank Concentration, and Firm Performance, World Development 97, 1-13.

Chithra, N., \& Selvam, M. (2013). Determinants of financial inclusion: An empirical study on the inter-state variations in India. Available at SSRN 2296096.

Demirguc-Kunt, A., Klapper, L., \& Randall, D, (2014). Islamic finance and financial inclusion: measuring use of and demand for formal financial services among Muslim adults, Review of Middle East Economics and Finance 10(2), 177-218.

Dyson, R.G., Allen, R., Camanho, A.S., Podimovski, V.V., Sarrico, C., Shale, S, (2001). Pitfalls and protocols in DEA, European Journal of Operational Research 132 (2), 245-259.

Evans, O, (2015). The Effects of Economic and Financial Development on Financial Inclusion in Africa, Review of Economic and Development Studies 1(1), 17-25.

Friedman, M. and Schwartz, A.J, (1963). A Monetary History of the United States, Princeton University Press, Princeton.

Fungáčová, Z., \& Weill, L, (2015). Understanding financial inclusion in China, China Economic Review 34, 196-206 
Goldsmith, R.W, (1969). Financial Structure and Development, Yale University Press, New Haven. Hafez, M. H., \& Halim, M. (2019). The efficiency of Islamic banks versus conventional banks: an empirical study of an emerging economy. Banks And Bank Systems, 14(2), 50-62.

Halicioglu, F, (2007). The financial development and economic growth nexus for Turkey, (No. 06/2007). EERI Research Paper Series.

Honohan, P, (2007). Cross country variation in household access to financial services, Paper prepared for the World Bank Conference on Access to Finance, March 15-16.

Jackson, P. M., \& Fethi, M. D, (2000). Evaluating the Technical Efficiency of Turkish Commercial Banks: An Application of DEA and Tobit Analysis, The International DEA Symposium, University of Queensland, Australia.

Jemric, I., \& Vujcic, B, (2002). Efficiency of banks in Croatia: A DEA approach, Comparative Economic Studies 44(2-3), 169-193.

Kabiru, K., \& Ibrahim, W. H. B. W. (2020). Can Islamic Banking Development Spur Financial Inclusion In OIC Member Countries?. Asian People Journal (APJ), 3(1), 170-185.

Kpodar, K. \& Andrianaivo, M, (2011). ICT, financial inclusion, and growth evidence from African countries, IMF Working Paper No. 73.

Kumar, N, (2013). Financial inclusion and its determinants: evidence from India. Journal of Financial Economic Policy, 5(1), 4-19.

Laha, A. Kuri, P. K. \& Kumar, P, (2011). Determinants of financial inclusion: A study of some selected districts of West Bengal, India, Selected Works 5(8), 1-28.

Lyons, A., Grable, J., \& Zeng, T. (2017). Infrastructure, urbanization, and the financial inclusion of Chinese households. Available at SSRN 3012453.

Marr, A. León, J. \& Ponce, F, (2014). Financial Inclusion of the Poor in Peru: Explanatory factors and determinants. Applied Econometrics and International Development 14(1), 101-130.

McKinnon, R.I, (1973). Money and Capital in Economic Development, Brookings Institution, Washington D.C.

Naceur, M. S. B., Barajas, M. A., \& Massara, M. A, (2015). Can Islamic Banking Increase Financial Inclusion?, International Monetary Fund Report No. 15-31.

Oyelami, L. O., Saibu, O. M., \& Adekunle, B. S, (2017). Determinants of Financial Inclusion in SubSahara African Countries, Covenant Journal of Business and Social Sciences 8(2).

Park, C. Y. \& Mercado, R. V, (2015). Financial inclusion, poverty, and income inequality in developing Asia, ADB Economics Working Paper Series, No. 426.

Patrick, H.T, (1966). Financial and economic growth in underdeveloped countries, Economic Development and Cultural Change 14, 174-187.

Pena, X., Hoyo, C. \& Tuesta, D, (2014). Determinants of financial inclusion in Mexico based on the 2012 National Financial Inclusion Survey (ENIF) (No. 1415).

Robinson, J, (1952). The Rate of Interest and Other Essays, Macmillan, London.

Sarma, M., \& Pais, J, (2011). Financial inclusion and development. Journal of international development 23(5), 613-628.

SBP (2016). Banking Statistics of Pakistan, http://sbp.org.pk/publications/anu_stats/index.htm

Shaw, E.S, (1973). Financial Deepening in Economic Development, Oxford University Press, New York.

Shaikh, S. A., Ismail, M. A., Shafiai, M. H. M., Ismail, A. G., \& Shahimi, S. (2017). Role of Islamic banking in financial inclusion: prospects and performance. In Islamic Banking (pp. 33-49). Palgrave Macmillan, Cham.

Sufian, F. and Mohamad Noor, M.A.N, (2009). The determinants of Islamic banks' efficiency changes: empirical evidence from the MENA and Asian banking sectors, International 
Journal of Islamic and Middle Eastern Finance and Management 2(2), 120-138.

Tuesta, D. Sorensen, G. Haring, A. \& Camara, N, (2015). Financial inclusion and its determinants: The Case of Argentina (No. 1503).

Yayar, R.,\& Karaca, S. S, (2014). Efficiency Analysis in Turkish Banking Sector, Niğde Üniversitesi İIBF Dergisi 7(2), 1-15.

Zins, A. \& Weill, L, (2016). The determinants of financial inclusion in Africa, Review of Development Finance 6(1), 46-57. 


\section{Appendices}

Table A1: Descriptive Statistics of Three Dimensions of Financial Inclusion (2007-2016)

\begin{tabular}{|c|c|c|c|c|c|c|c|c|c|c|c|c|c|c|}
\hline & \multicolumn{4}{|c|}{ D1 } & \multicolumn{8}{|c|}{ D2 } & \multicolumn{2}{|c|}{ D3 } \\
\hline & d11 & $\mathrm{d}_{12}$ & d13 & d14 & $\mathrm{d} 21$ & $\mathrm{~d} 22$ & $\mathrm{~d} 23$ & $\mathrm{~d} 24$ & $\mathrm{~d} 25$ & $\mathrm{~d} 26$ & $\mathrm{~d} 27$ & $\mathrm{~d} 28$ & $\mathrm{~d}_{31}$ & d32 \\
\hline Mean & 25.25 & 310.44 & 30.51 & 22.67 & 9.82 & 6.42 & 14.03 & $9 \cdot 30$ & 37.50 & 53.25 & 81.92 & 129.04 & 5.50 & $53 \cdot 31$ \\
\hline Median & 25.25 & $309 \cdot 34$ & 28.55 & 11.93 & 9.00 & 5.98 & 13.82 & 9.20 & 38.00 & 52.50 & 57.27 & 86.61 & 5.50 & 53.66 \\
\hline Maximum & 29.30 & 380.10 & 39.96 & 77.90 & 16.05 & 9.83 & 16.90 & 10.36 & 40.00 & 56.00 & 189.04 & 301.78 & 6.00 & 55.96 \\
\hline Minimum & 21.75 & 233.25 & 26.13 & 2.00 & 5.50 & 4.00 & 11.79 & 8.57 & 34.00 & 51.00 & 16.01 & 24.64 & 5.00 & 50.04 \\
\hline Std. Dev. & 2.60 & 51.27 & 4.83 & 27.33 & 3.82 & 2.13 & 1.84 & 0.66 & 2.14 & 2.38 & 72.48 & 117.22 & 0.53 & 2.36 \\
\hline Skewness & 0.07 & -0.09 & 1.06 & 1.24 & 0.46 & 0.43 & 0.29 & 0.39 & -0.42 & 0.30 & 0.41 & 0.44 & 0.00 & -0.38 \\
\hline Kurtosis & 1.91 & 1.82 & 2.76 & 3.04 & 1.84 & 1.80 & 1.76 & 1.77 & 2.09 & 1.29 & 1.49 & 1.52 & 1.00 & 1.67 \\
\hline Jarque-Bera & 0.40 & 0.47 & 1.53 & 2.04 & 0.73 & 0.73 & 0.63 & 0.70 & 0.51 & 1.10 & 0.98 & 0.99 & 1.33 & 0.78 \\
\hline Probability & 0.82 & 0.79 & 0.47 & 0.36 & 0.69 & 0.69 & 0.73 & 0.70 & 0.77 & 0.58 & 0.61 & 0.61 & 0.51 & 0.68 \\
\hline Observations & 8 & 8 & 8 & 8 & 8 & 8 & 8 & 8 & 8 & 8 & 8 & 8 & 8 & 8 \\
\hline
\end{tabular}

Source: Authors' calculations 
Table A2: Dimension Index of Three Dimensions of Financial Inclusion

\begin{tabular}{|c|c|c|c|c|c|c|c|c|c|c|c|c|c|c|}
\hline \multirow{2}{*}{ Years } & \multicolumn{4}{|c|}{ D1 } & \multicolumn{8}{|c|}{ D2 } & \multicolumn{2}{|c|}{ D3 } \\
\hline & d11 & $\mathrm{d} 12$ & d13 & $\mathrm{d} 14$ & $\mathrm{~d} 21$ & $\mathrm{~d} 22$ & $\mathrm{~d} 23$ & $\mathrm{~d} 24$ & $\mathrm{~d} 25$ & $\mathrm{~d} 26$ & $\mathrm{~d} 27$ & $\mathrm{~d} 28$ & $\mathrm{~d}_{31}$ & $\mathrm{~d}_{32}$ \\
\hline 2007 & 0.99 & 0.02 & 0.95 & -0.03 & 0.00 & 0.00 & 0.00 & 0.00 & 1.00 & 1.00 & -0.09 & -0.09 & 0.00 & 0.50 \\
\hline 2008 & 1.00 & 0.03 & 1.00 & -0.03 & 0.08 & 0.10 & 0.12 & 0.16 & 0.86 & 0.33 & -0.09 & -0.09 & 0.50 & 0.72 \\
\hline 2009 & 0.74 & 0.00 & 0.57 & 0.00 & 0.15 & 0.18 & 0.18 & 0.19 & 0.86 & 0.83 & 0.00 & 0.00 & 0.50 & 0.93 \\
\hline 2010 & 0.56 & 0.17 & 0.38 & 0.01 & 0.21 & 0.23 & 0.24 & 0.21 & 0.86 & 0.83 & 0.01 & 0.00 & 0.50 & 0.88 \\
\hline 2011 & 0.49 & 0.35 & 0.20 & 0.03 & 0.28 & 0.30 & 0.33 & 0.29 & 0.57 & 0.83 & 0.01 & 0.01 & 0.50 & 1.00 \\
\hline 2012 & 0.41 & 0.46 & 0.13 & 0.11 & 0.36 & 0.38 & 0.44 & 0.40 & 0.57 & 0.00 & 0.07 & 0.06 & 0.50 & 0.50 \\
\hline 2013 & 0.28 & 0.57 & 0.07 & 0.15 & 0.51 & 0.53 & 0.58 & 0.55 & 0.57 & 0.00 & 0.40 & 0.38 & 1.00 & 0.72 \\
\hline 2014 & 0.22 & 0.74 & 0.05 & 0.23 & 0.65 & 0.67 & 0.70 & 0.67 & 0.43 & 0.00 & 0.67 & 0.66 & 1.00 & 0.00 \\
\hline 2015 & 0.05 & 0.90 & 0.00 & 0.64 & 0.84 & 0.85 & 0.85 & 0.85 & 0.14 & 0.33 & 1.00 & 1.00 & 1.00 & 0.00 \\
\hline 2016 & 0.00 & 1.00 & 0.04 & 1.00 & 1.00 & 1.00 & 1.00 & 1.00 & 0.00 & 0.17 & 0.87 & 0.90 & 1.00 & 0.39 \\
\hline
\end{tabular}

Source: Authors' calculations. 
Review of Economics and Development Studies, Vol. 6 (4) 2020, 739-758

Table A3: Descriptive Statistics of Key Input and Output Variables (2007-2016)

\begin{tabular}{|c|c|c|c|c|}
\hline Variables & Mean & Standard deviation & Max & Min \\
\hline \multicolumn{5}{|c|}{2007} \\
\hline Deposits & $137,998,534$ & $162521165 \cdot 3$ & $591,907,435$ & 1879587 \\
\hline Admin expenses & $4,080,435$ & 5010387.306 & $18,297,279$ & 165999 \\
\hline Advances & $93,792,241$ & 108971410.5 & $382,172,734$ & 2118347 \\
\hline Investments & $46,155,904$ & 55064439 & $211,146,038$ & 1318657 \\
\hline \multicolumn{5}{|c|}{2008} \\
\hline Deposits & 151167482 & 179766920.6 & 624939016 & 1892018 \\
\hline Admin expenses & 5221954.85 & 5843319.157 & 21348016 & 367798 \\
\hline Advances & 111124508 & 130695603.2 & 456355507 & 2526322 \\
\hline Investments & 39043187.8 & 45784223.24 & 170822491 & 2045146 \\
\hline \multicolumn{5}{|c|}{2009} \\
\hline Deposits & 171154037 & 196902040.6 & 726464825 & 2203152 \\
\hline Admin expenses & 5860863.88 & 6229720.761 & 22571470 & 451930 \\
\hline Advances & 112896645 & 132270999.7 & 475243431 & 2500916 \\
\hline Investments & 62167641.8 & 63644218.97 & 217642822 & 2822723 \\
\hline \multicolumn{5}{|c|}{2010} \\
\hline Deposits & 197808125 & 223126845.6 & 832151888 & 2225822 \\
\hline Admin expenses & 6626376.04 & 7071170.392 & 26202577 & 533679 \\
\hline Advances & 119875165 & 133305770.4 & 477506564 & 2510780 \\
\hline Investments & 77833922.6 & 83702158.09 & 301323804 & 2892131 \\
\hline \multicolumn{5}{|c|}{2011} \\
\hline Deposits & 232863522 & 257671742.5 & 933631525 & 2647157 \\
\hline Admin expenses & 8066601.92 & 8319288.915 & 30945203 & 561436 \\
\hline Advances & 115962143 & 131616566.9 & 595630955 & 26243 \\
\hline Investments & 85758449.2 & 90002518.24 & 319353392 & 1484124 \\
\hline \multicolumn{5}{|c|}{2012} \\
\hline Deposits & 244583673 & 274665467.3 & 1214963700 & 3328001 \\
\hline Admin expenses & 8973154.96 & 9239587.127 & 35921902 & 595700 \\
\hline Advances & 132216086 & 157308389.7 & 734349374 & 56596 \\
\hline Investments & 102934991 & 105543197.5 & 381245903 & 7263885 \\
\hline \multicolumn{5}{|c|}{2013} \\
\hline Deposits & 303795617 & 354518045.1 & 1401229814 & 3713111 \\
\hline Admin expenses & 9701553.38 & 10147607.62 & 37677868 & 605052 \\
\hline Advances & 151424980 & 185146557.8 & 713042502 & 3894413 \\
\hline Investments & 144312522 & 194522189.5 & 826062308 & 2653388 \\
\hline \multicolumn{5}{|c|}{2014} \\
\hline Deposits & 350303093 & 384026715 & 1524644784 & 3342155 \\
\hline Admin expenses & 11106713.2 & 11332383.08 & 41518462 & 634381 \\
\hline Advances & 183578032 & 190919508 & 731980299 & 4692044 \\
\hline Investments & 196972765 & 224890812.9 & 922691101 & 1379486 \\
\hline \multicolumn{5}{|c|}{2015} \\
\hline Deposits & 396365297 & 430485112.2 & 1634944470 & 4768752 \\
\hline Admin expenses & 12160274.6 & 12885481.01 & 48400384 & 682821 \\
\hline Advances & 198844948 & 193206721.1 & 702561836 & 8585373 \\
\hline Investments & 249378963 & 304596717 & 1244887008 & 48240 \\
\hline \multicolumn{5}{|c|}{2016} \\
\hline Deposits & 477261692 & 484192783.5 & 1885959026 & 5228716 \\
\hline Admin expenses & 13931647.2 & 13553803.29 & 54416640 & 740332 \\
\hline Advances & 217126048 & 197108763 & 748466297 & 2771720 \\
\hline Investments & 296706290 & 325161208.4 & 1344404771 & 4869535 \\
\hline
\end{tabular}

Note: The values are thousands of rupees. 